\title{
MURELLO PER PIGNATTE. TOPENIŠTĚ S TOPNÝMI ŠACHTAMI V KUCHYNÍCH PRAŽSKÉHO HRADU
}

\author{
MIROSLAVA CEJPOVÁ - MAGDALÉNA BIEDERMANOVÁ
}

\begin{abstract}
Abstrakt: Práce se zabývá kuchyňskými topeništi s ohništěm umistěným na kovovém roštu v šachtě nalezenými na Pražském hradě, která jsou v zahraniční literatuře dobově označována napřiklad jako „fourneau“ či „potager“ ve francouzském prostředi, nebo jako „,murello per pignatte“ v díle Bartlomea Scappiho. Tato topeniště se zde in situ dochovala tři. Dvě datovaná do druhé poloviny 16. století jsou v Ludvikově kř́lle Starého paláce, jedno datované do druhé poloviny 19. století je v jižním kř́dle v suterénu tzv. Maxmiliánových kuchyní. Dalši topeniště, která se nacházela v dnes již neexistujících kuchyních, známe díky historickým plánům z 18. a 19. století. Topeniště byla bud' samostatná, většinou přizdèná k obvodové zdi, nebo byla součástí podesty pro otevrený ohen̆, zpravidla se nacházela na okraji jeji kratši strany. Některá topeniště nemaji napojení na komín, což potvrzuje předpoklad, že produkovala minimum kouře, který bylo možné odvětrat oknem.
\end{abstract}

Klíčová slova: Pražský hrad-kuchyně - topeniště - 2. polovina 16. až 19. století.

\section{Murello per pignatte. Furnaces with heating shafts in the kitchens of Prague Castle}

Abstract: This article discusses kitchen furnaces with hearths on a metal grid in a shaft, discovered at Prague Castle. In specialist literature of foreign provenance, they are referred to as fourneau or potager in the French milieu, or as murello per pignatte by Bartlomeo Scappi. Three furnaces were preserved at Prague Castle in situ. Two are dated to the second half of the 16th century and are located in the Ludwig Wing of the Old Palace, one is dated to the second half of the 19th century and is in the south wing, in the basement of "Maxmilian kitchens". Further furnaces located in now non-existent kitchens are known from historical plans from the 18th and 19th centuries. They were either individual, usually added to the perimeter wall, or were part of a base for open fire, typically by its shorter side. Some furnaces were not connected with chimneys, which confirms the assumption that they produced minimum smoke which could be eliminated by airing the room.

Key words: Prague Castle - kitchen - furnace - second half of the 16th century - 19th century.

V letech 2016-2017 byl prováděn průzkum Ludvíkova křídla Pražského hradu zaměřený na vytápění a kuchyňská topeniště. Během průzkumu byla dokumentována dvě kuchyňská topeniště, která byla jen stručně popsána ve stavebně historickém průzkumu, jejich konstrukce a fungování však v naší odborné literatuře publikovány nebyly. Analogie i odborná sdělení se podařilo zjistit v literatuře zahraniční. Pro zmíněná topeniště se zatím nepodařilo objevit v dobové literatuře český název, ve francouzských pramenech jsou zmiňovány např́iklad jako potager či fourneau (Sirot 2011, 135), v pramenech italských např́klad jako murello per pignatte (Scappi 1570, v. 258), možnost převzetí některého z těchto výrazů se však nejeví jako opodstatnitelná, proto budeme pro účely tohoto článku používat termín topeniště s šachtou.

Jedná se o topeniště určená pro vaření na regulovaném ohni nebo pro ohřev či přihřátí již hotových jídel (Sirot 2011, 135). Obdobná, ale mladší topeniště se pak podařilo zjistit cíleně zaměřeným průzkumem i na dalších lokalitách a v dokumentech Staré plánové sbírky uložené v Archivu Pražského hradu (dále APH, SPS; obr. 1). Popis a fungování topeništ' v Ludvíkově kř́idle byly již zveřejněny $\mathrm{v}$ rámci publikace výše zmíněného průzkumu (Biedermanová-Cejpová 2017, 112-115, 124-129), pro konferenci Archaeologia historica byl prripraven příspěvek zaměřený na další topeniště doložená v plánové dokumentaci Hradu a na některé jejich analogie. Sledovaná topeniště obsahují jednu nebo více šachet, ve kterých je umístěn kovový rošt. Na tento rošt se vkládaly jinde připravené rozžhavené uhlíky, prŕípadně i dřevěné uhlí. Popel propadával roštem do spodní části šachty, která se zalamovala do pravého úhlu a ústila ve stěně topeniště, případně až u podlahy místnosti. Tímto manipulačním otvorem se vybíral popel. Průběh spalování, a tedy i intenzita hoření se pravděpodobně regulovala prŕstupem vzduchu pomocí 


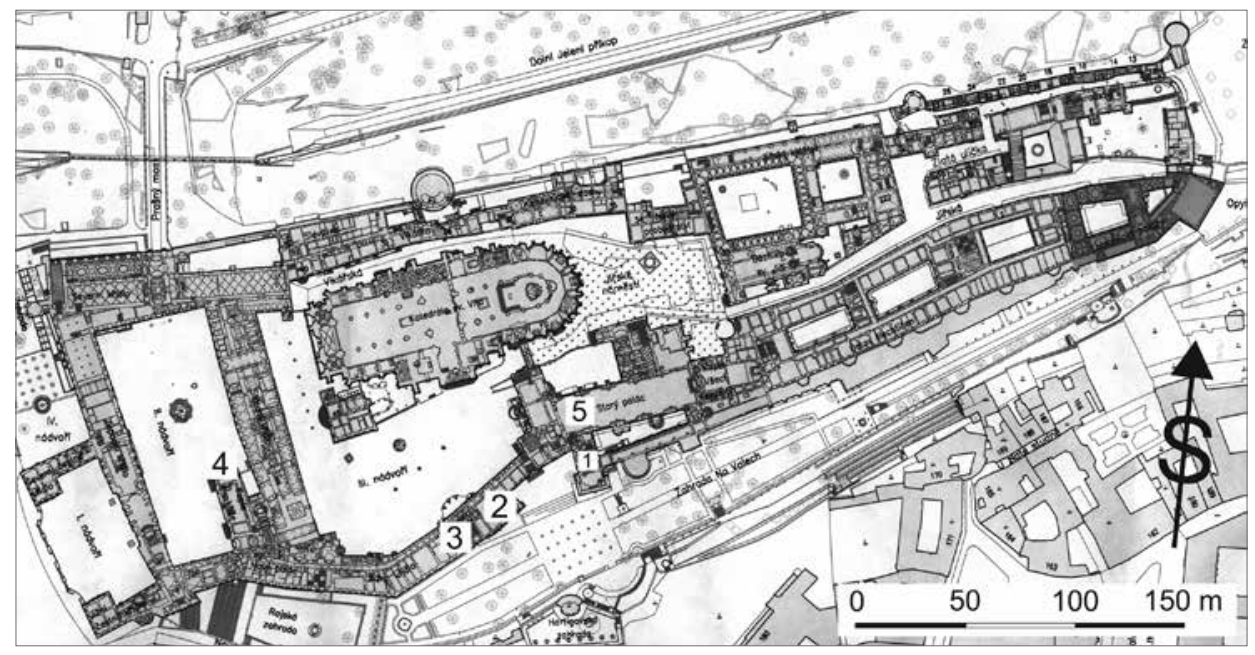

Obr. 1. Poloha kuchyní v areálu Pražského hradu. 1 - Ludvíkovo křídlo, 2 - Maxmiliánovy kuchyně, 3 - tzv. císařovnina kuchyně, 4 - kuchyně postavená př́i korunovaci Karla VI., 5 - korunovační kuchyně ve Starém paláci.

Abb. 1. Lage der Küchen im Areal der Prager Burg. 1 - Ludwígsflügel, 2 - Maximiliansküchen, 3 - sog. Kaiserinnenküche, 4 - zur Krönung von Karl VI. erbaute Küche, 5 - Krönungsküche im Alten Palast.

zakrývání manipulačního otvoru. Ovlivňoval ho zřejmě i tvar otvoru a velikost nádoby, v níž se pokrm vařil či ohříval (Biedermanová-Cejpová 2017, 104, 112-115).

V době přípravy článku vyšla kniha Zámecké kuchyně od V. Štajnochra, která tomuto typu topeništ' věnuje jednu z podkapitol. Autor zde definoval „topeniště s vhloubeným ohništěm“, která rozdělil podle konstrukce do čtyř skupin na topeniště s vhloubeným ohništěm shora a zpředu otevřeným, topeniště s vhloubeným ohništěm se čtvercovým či kruhovým ústím, topeniště $\mathrm{s}$ vhloubeným ohništěm $\mathrm{s}$ roštem a popelníkem a topeniště s vhloubeným ohništěm s roštem. Pro francouzský kontext přejímá též výraz potager, jehož archaickou formu popisuje jako topeniště se sérií vhloubených ohnišst' opatřených otevřeným čtvercovým či kruhovým ústím s roštem (Štajnochr 2017, 85-95).

Topeniště dochovaná v Ludvíkově křídle Pražského hradu je možné přiřadit dle výše uvedeného dělení $\mathrm{k}$ topeništím s vhloubeným ohništěm s roštem a popelníkem. Nachází se ve čtvrtém a pátém podlaží křídla. První topeniště bylo někdy ve třetí čtvrtině 16 . století vloženo do niky ve zdi oddělující Ludvíkovo křídlo od Vladislavského sálu v severní místnosti čtvrtého podlaží (obr. 2). Nika vznikla na místě původního krbu. Topeniště vysoké $60 \mathrm{~cm}$ je $138 \mathrm{~cm}$ dlouhé a $60 \mathrm{~cm}$ široké. I když má přední část poškozenou, je možné rekonstruovat jeho podobu. Obsahovalo tři symetricky umístěné svislé topné šachty o průřezu zhruba $24 \times 24 \mathrm{~cm}$, které končí $9 \mathrm{~cm}$ nad podlahou místnosti. Př́stup do spodní úrovně šachet umožňovaly manipulační otvory, které ústily na čelní straně topeniště. V šachtách se v hloubce $22 \mathrm{~cm}$ dochoval otisk kruhového roštu uloženého do silné vrstvy malty. Obdobná je konstrukce topeniště v pátém podlaží (obr. 3). Bylo vložené do výklenku okna v prostoře určené $\mathrm{k}$ obsluze kamen $\mathrm{v}$ sále, přímo na keramickou dlažbu, pravděpodobně až po požáru, který místnost poškodil v roce 1541 . Jeho rozměry dané nikou okna jsou $126 \times 59 \times 156 \times 52 \mathrm{~cm}$, výška je $54 \mathrm{~cm}$. Topné šachty jsou o několik centimetrů menší než ve čtvrtém podlaží, dosahují až na podlahu místnosti, kde se otevírají manipulační otvory. V hloubce $20 \mathrm{~cm}$ od povrchu topeniště byl zazděný rošt, podle otisků ho tvořily volné tyče. Obě topeniště byla postavena z cihel na vápennou maltu a omítnuta (Biedermanová-Cejpová 2017, 104, 112-115).

Topeniště v Ludvíkově křídle, která se nacházela mimo vlastní kuchyni, sloužila k přihřátí pokrmů před podáváním. Ve čtvrtém podlaží pro úředníky české kanceláře, která sem byla 

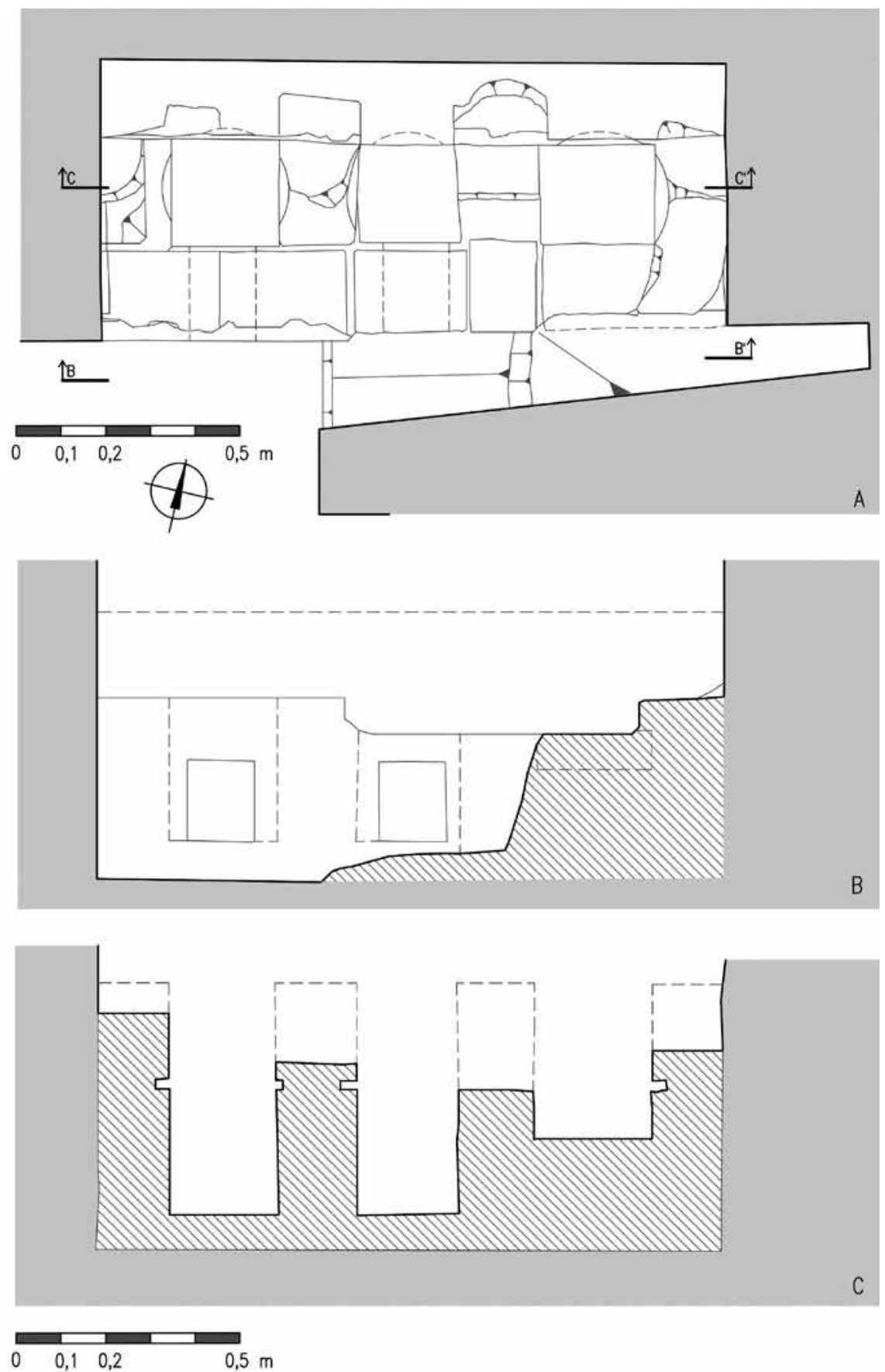

Obr. 2. Topeniště se šachtami ve čtvrtém podlaží Ludvíkova křídla. Podle Cejpová-Biedermanová 2017.

Abb. 2. Feuerstätte mit Schächten im vierten Stockwerk des Ludwigsflügels. Nach Cejpová-Biedermanová 2017. 


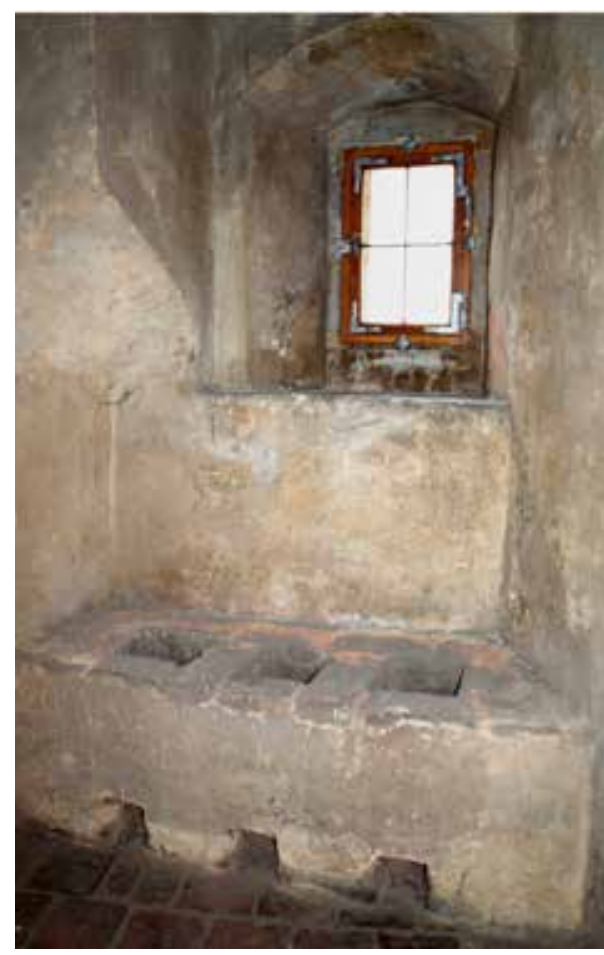

Obr. 3. Topeniště s šachtami v pátém podlaží Ludvíkova křídla. Foto M. Cejpová.

Abb. 3. Feuerstätte mit Schächten im fünften Stockwerk des Ludwigsflügels. Foto M. Cejpová.

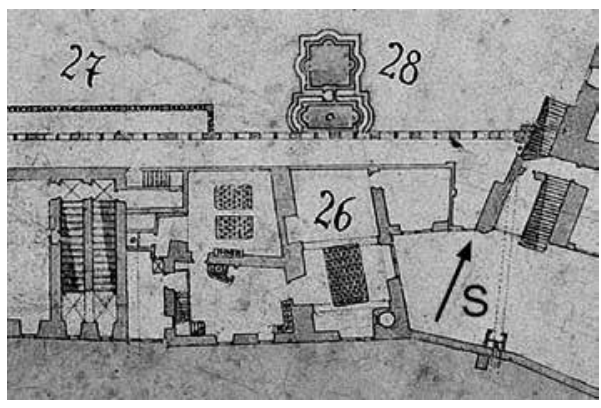

Obr. 4. Tzv. Maxmiliánovy kuchyně před tereziánskými úpravami. Zdroj APH, SPS, sign. 157A, inv. č. 1.

Abb. 4. Sog. Maximiliansküchen vor den theresianischen Umbauten. Quelle Archiv der Prager Burg, Alte Plänesammlung, Sign. 157A, Inv.-Nr. 1.

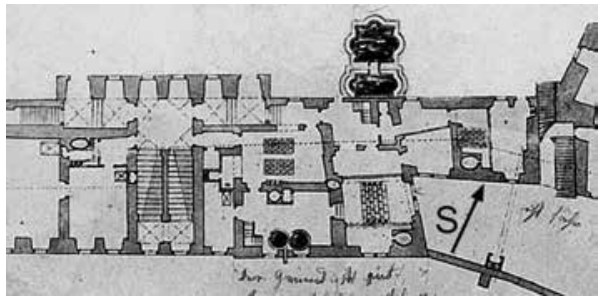

Obr. 5. Tzv. Maxmiliánovy kuchyně těsně před tereziánskými úpravami, kolem roku 1758. Zdroj APH, SPS, sign. 157A, inv. ̌̌. 2 .

Abb. 5. Sog. Maximiliansküchen kurz vor den theresianischen Umbauten, um das Jahr 1758. Quelle Archiv der Prager Burg, Alte Plänesammlung, Sign. 157A, Inv.-Nr. 2.

umístěna někdy mezi lety 1543-1576, v pátém podlaží pro královskou hodovní síň, která zde byla do 17. století. Zrušena byla až mezi lety 1620-1676, pravděpodobně v souvislosti s dokončením stavebních úprav jižního křídla Ferdinandem III. v letech 1643-1644 (Vilímková 1972, 100101). Nahradila ji říšská kancelář a předpokládáme, že topeniště pak sloužilo pro její úředníky.

Topeniště s topnými šachtami byla též součástí vybavení hradních kuchyní. Tyto kuchyně, kromě mladší fáze tzv. Maxmiliánových kuchyní, se bohužel do dnešní doby nedochovaly, můžeme však vycházet z plánů Staré plánové sbírky uložených v Archivu Pražského hradu a ze zpracovaných stavebně historických průzkumů, především částí zabývajících se historií. Topeniště s šachtami je možné identifikovat na plánech zachycujících půdorysy. Jejich zakreslení však není zcela jednoznačné, protože nepoznáme, zda součástí konstrukce byl i rošt. Domníváme se, že se jedná o topeniště s šachtou s roštem a popelníkem, která by se v prostředí panovnického dvora nejlépe hodila na přípravu náročných jídel pro královskou tabuli.

Nejstarší známé kuchyně se nacházely západně od Starého paláce. Jejich suterén je dosud zachovaný ve východní části jižního paláce. Kuchyně bývají označované jako Maxmiliánovy, jsou však starší, vznikly v rámci jagellonské přestavby Pražského hradu. Byly postaveny na místě kuchyní starších nebo vznikly jejich přestavbou (Vilímková-Kašička 1976, 97-70). V písemných pramenech jsou poprvé uvedeny v roce 1554 (Vilímková 1972, 44). Kuchyně tvořil hloubkový dvojtrakt, který se nacházel v parkánu mezi románskou a gotickou hradbou. Jeho zadní čelo tvořila románská hradba, na niž byla přistavěna chodbovitá nástavba, která kuchyně převyšovala. Chodba spojovala starý královský palác s novým stavením arcivévody Ferdinanda 


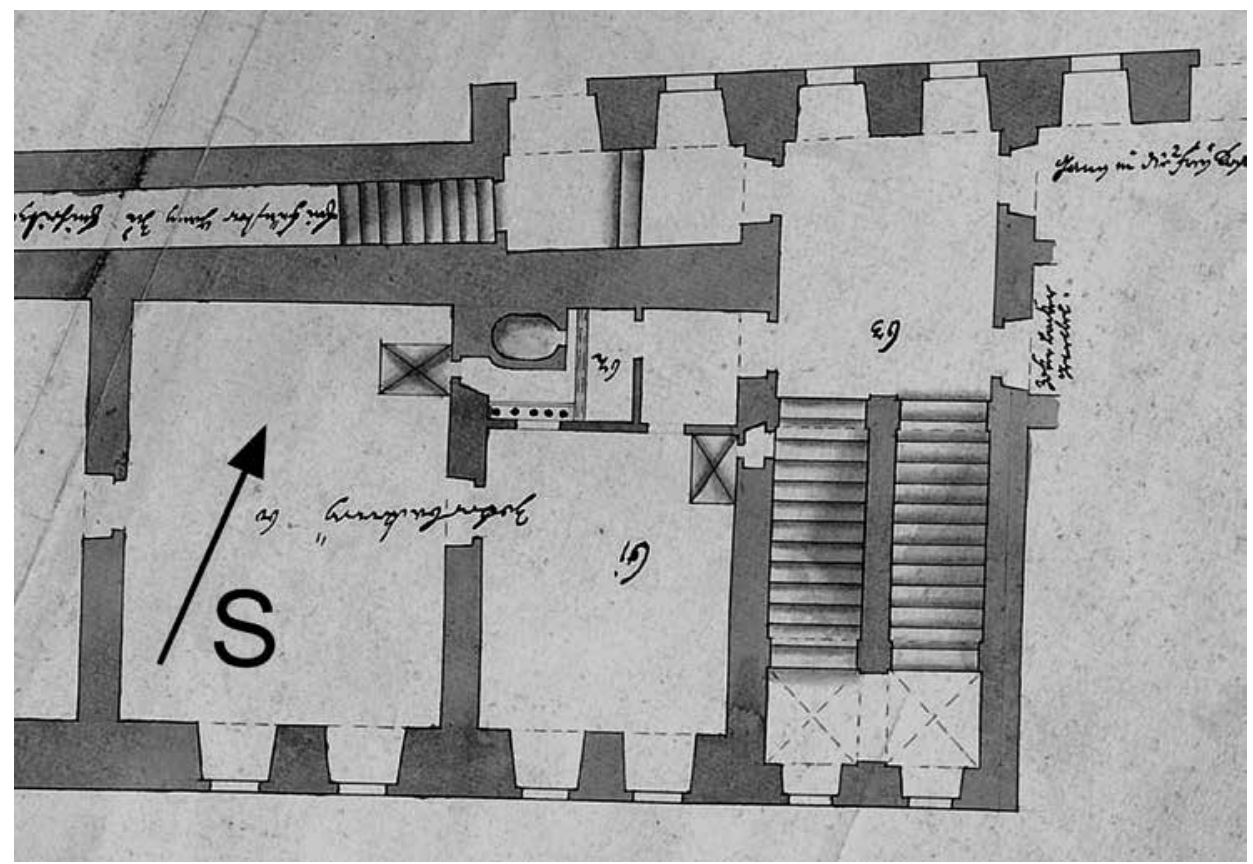

Obr. 6. Císařovnina kuchyně v roce 1744. Zdroj APH, SPS, sign. 109, inv. č. 2.

Abb. 6. Kaiserinnenküche im Jahr 1744. Quelle Archiv der Prager Burg, Alte Plänesammlung, Sign. 109, Inv.-Nr. 2.

a umožňovala spojení hradních kuchyní s hodovními síněmi obou paláců (Vilímková-Kašička 1976, 67-70). V př́zemí každého traktu se nacházela prostora určená přípravným pracím a vlastní kuchyně zaklenutá klášterní klenbou, jejíž vrchol se otevíral do komína (Cejpová, v tisku). V západním traktu byly $\mathrm{v}$ kuchyni dvě menší podesty na vaření, ve východním traktu byla podesta topeniště jen jedna, ale větší. Poloha a počet topeništ' s topnými šachtami se měnily. Na nejstarších plánech z doby před tereziánskou přestavbou ${ }^{1}$ jsou jen $\mathrm{v}$ západním traktu, šachty jsou umístěny $v$ topeništích při obvodových zdech, čtyři ve vlastní kuchyni, tedy s př́mým odtahem do komína, sedm v sousední př́ípravné místnosti, kde mohlo ventilaci zajistit pouze okno (APH, SPS, sign. 110, inv. č. 35; sign. 157A, inv. č. 1). Liší se i zakreslení šachet, na plánu 110/35 jsou pravoúhlé, zhruba čtvercové, na plánu 157A/1 jsou kruhové (obr. 4). Bližší určení stáří plánu 110/35 neznáme, plán 157A/1 vznikl po roce 1723, protože je na něm zakreslena další kuchyně postavená v roce 1723. Můžeme jen spekulovat, zda rozdílný průřez šachet ve shodně zakreslených topeništích ukazuje na jejich přestavbu, nebo je to detail, kterému kreslíř nevěnoval pozornost.

Ve staré plánové sbírce se zachovaly nejen plány skutečného stavu, ale i plánovaných stavebních úprav. Do roku 1722 klade M. Vilímková plán se signaturou 109, inventárním číslem 1, který zachycuje návrh na úpravy jižního křídla v souvislosti s připravovanou korunovací Karla VI. v roce 1723. Zpracoval ho stavební písař J. H. Dienebier (Vilímková 1972, 112). Podle tohoto návrhu měla být topeniště $\mathrm{s}$ šachtami umístěna $\mathrm{v}$ obou kuchyních, $\mathrm{v}$ západní $\mathrm{v}$ přízedních zídkách, ve východní na obou kratších stranách topeniště. Další plán zachycující Maxmiliánovy kuchyně je až z roku 1758 (APH, SPS, sign. 157A, inv. č. 2). Situace se od zařízení kuchyní navrženého v roce 1722 liší jen v detailech (obr. 5).

1 Datace plánů uvedená v textu vychází z inventáře Sbírky historických plánů (Neznámý 1973). 


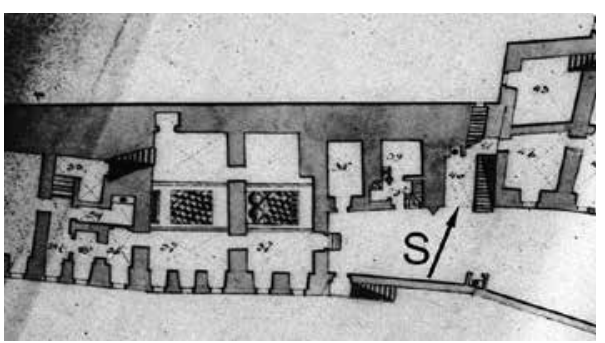

Obr. 7. Tzv. Maxmiliánovy kuchyně po přestěhování do suterénu. Zdroj APH, SPS, sign. 157A, inv. č. 20.

Abb. 7. Sog. Maximiliansküchen nach Umzug ins Souterrain. Quelle Archiv der Prager Burg, Alte Plänesammlung, Sign. 157A, Inv.-Nr. 20.
Zajímavá kuchyně se nachází západně od tzv. Maxmiliánových kuchyní a císařovnina schodiště (schodiště vedle kuchyní). Tuto kuchyni snad můžeme spojovat se soukromou císařovninou kuchyní, která se měla zřídit ve staré pekárně vedle císařovnina schodiště při přípravách na korunovaci Karla VI. (Vilímková 1972, 114-115). Kuchyně je zakreslena na návrhu úprav z roku 1722 (APH, SPS, sign. 109, inv. č. 1), na plánu zachycujícím úpravy provedené v souvislosti s korunovací Marie Terezie v roce 1743 (APH, SPS, sign. 109, inv. č. 2) i na plánu z roku 1758. I když se plány $\mathrm{v}$ prostoru císařovniny kuchyně v detailech liší (topeniště s šachtami je zakreslené pod dýmníkem i mimo něj), jedno mají společné. V kuchyni se nachází pec, předpokládáme, že určená pro pečení masa, a topeniště s šachtami, chybí podesta pro otevřený oheň (obr. 5, 6). Zdá se, že pro úpravu jídla určeného na stůl císařovny toto postačovalo.

Při tereziánské přestavbě Pražského hradu, někdy mezi lety 1758-1761, byly tzv. Maxmiliánovy kuchyně přesunuty do prvního suterénu (Cejpová, v tisku). I zde byla zachována původní dvoutraktová dispozice, ve střední části západního i východního traktu bylo topeniště, na východě záhy doplněné dvěma pecemi (obr. 7). Topeniště s topnými šachtami byla na západě při obvodových zdech, na východě na okraji topeniště (APH, SPS, sign. 157A, inv. č. 20, rok 1792), později byla pouze při zdech v západní kuchyni (APH, SPS, sign. 157A, inv. č. 26 a 32, rok 1819). V roce 1836 byl zpracován plán na modernizaci kuchyní (APH, SPS, sign. 108, inv. č. 2). Vedle dvou sporáků a pece měla být $\mathrm{v}$ obou kuchyních také samostatná topeniště s šachtami. $\mathrm{Z}$ dochovaných plánů vyplývá, že přestavba plánovaná v roce 1836 realizována nebyla, k modernizaci kuchyní došlo až po roce 1853. Nabízí se, že to bylo při př́ipravě kuchyní pro plánovanou korunovaci Františka Josefa I. v gotických prostorách Starého paláce Pražského hradu v 60. a 70. letech 19. století, tuto hypotézu by však musel potvrdit archivní průzkum. Modernizovanou kuchyni vidíme na plánu z roku 1899 (APH, SPS, sign. 157A, inv. č. 109). Část vybavení zaznamenaného na tomto plánu se v kuchyních, které jsou součástí depozitářu Archivu Pražského hradu, dochovala do dnešní doby. Je mezi nimi i topeniště se třemi topnými šachtami, které mají každá jiný tvar ústí.

V souvislosti s přípravami na korunovaci Karla VI. v roce 1723 došlo ke stavebním úpravám hradu. Jednou z nich bylo zřízení nové kuchyně, která byla přistavěna ke kř́ídlu vysunutému od jihu do druhého hradního nádvoří (Vilímková-Kašička 1976, 67). Dnes se zde nachází kaple sv. Kř́že, podobu kuchyně tak známe jen z dochovaných plánů (APH, SPS, sign. 113, inv. č. 1; sign. 114, inv. č. 1). Kuchyně byla přízemní, měla obdélný půdorys (obr. 8). Nad její střední částí se tyčil dymníkový komín na obdélném půdoryse nesený šesti pilíři. Pod komínem se nacházela velká obdélná podesta na vaření, přístupná ze čtyř stran, severně od ní byla mezi ústími dvou sousedících pecí menší podesta. Na kratší straně většího topeniště bylo umístěno devět šachet (Cejpová, v tisku).

K poslednímu přemístění velké hradní kuchyně došlo při tereziánské přestavbě Pražského hradu (Vilímková 1972, 123). Nová kuchyně v západním křídle vznikla v letech 1757-1758 přestavbou domu nejvyššího komořího. Existovala až do roku 1928, kdy byla zbourána v rámci stavebních úprav, na jejím místě byla vybudována sloupová síň podle návrhu arch. J. Plečnika. Zatím se na žádném z plánů, které zachycují půdorys kuchyně, nepodařilo objevit topeniště s topnými šachtami. Souběžně s touto kuchyní fungovaly i tzv. Maxmiliánovy kuchyně přemístěné do suterénu jižního paláce, ve kterých tato topeniště byla. Zda byla v kuchyních připravována strava pro odlišné skupiny strávníků, by mohl osvětlit archivní průzkum (Cejpová, v tisku). 


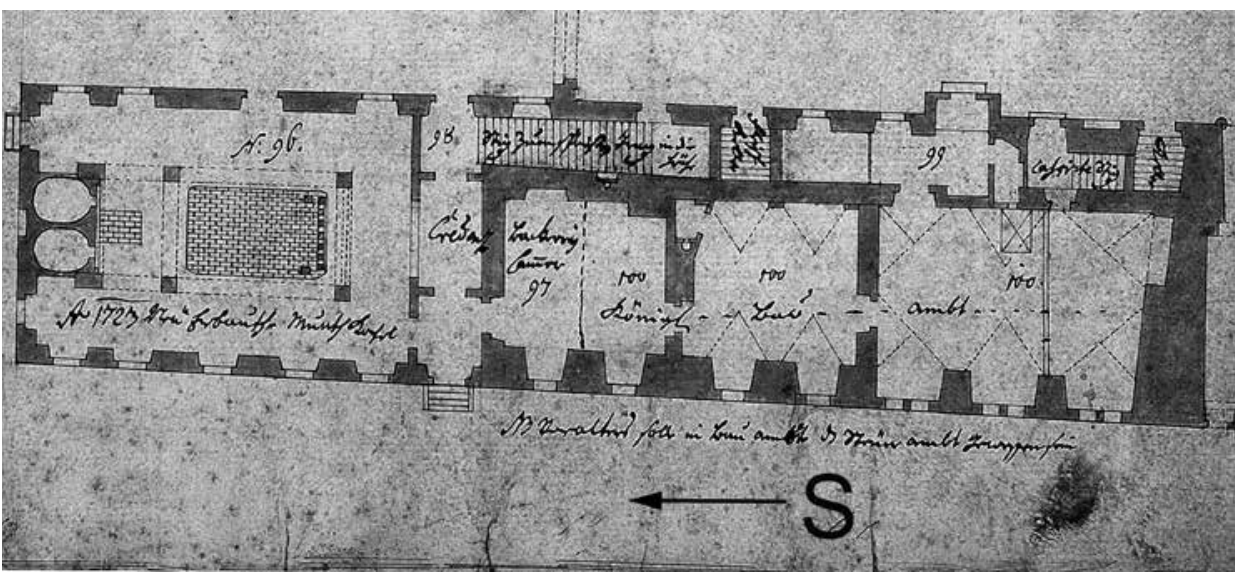

Obr. 8. Kuchyně postavená v roce 1723 pro korunovaci Karla VI. Zdroj APH, SPS, sign. 113, inv. č. 1.

Abb. 8. Im Jahr 1723 zur Krönung von Karl VI. erbaute Küche. Quelle Archiv der Prager Burg, Alte Plänesammlung, Sign. 113, Inv.-Nr. 1.

V 60. a 70. letech 19. století se připravovala korunovace Františka Josefa I. Pro plánované oslavy měly být zř́zeny kuchyně v gotickém patře starého hradního paláce. Mezi lety 1861-1872 vznikla řada návrhů tzv. korunovačních kuchyní v tomto prostoru. Na většině plánů se objevují vedle tahových sporáků ještě př́izední topeniště s šachtami v několika velikostech, některé i značně rozměrné.

Na plánové dokumentaci v Archivu Pražského hradu je zachyceno množství dalších, menších kuchyní. Tyto vedlejší kuchyně byly určeny k soukromé potřebě různých arcivévodů a jejich doprovodů, př́ípadně dalších vzácných hostů při jejich návštěvách v Praze. Některé z nich byly také součástí bytů obývaných úředníky a dalšími zaměstnanci (Vilímková-Kašička 1976, 67). I některé z těchto kuchyní byly vybaveny topeništi s šachtami. Pro jejich posouzení by bylo třeba vědět, pro koho byla kuchyně určena. To je již úkol pro archivní rozbor dochované dokumentace a pramenů.

\section{Závěr}

Topeniště s topnými šachtami (předpokládáme, že i u topeništ' zachycených pouze na plánech se jedná o variantu s roštem a popelníkem) byla využívána na Pražském hradě již od 16. století. Topeniště dochovaná v Ludvíkově křídle Starého paláce jsou zatím nejstarší známá v českých zemích. Byla využivána pro ohřev nebo přihřátí již hotových jídel, z vyhodnocení plánů je však zřejmé, že měla své zastoupení i v hradních kuchyních. Poloha topeništ' jak v Ludvíkově křídle, tak v přízemí Maxmiliánových kuchyní nebo v císařovnině kuchyni dokládá, že při vaření na uhlících nebo dřevěném uhlí nebylo nutné přímé odkouření do komína, ale postačovalo prrípadné odvětrání oknem. Zajímavá je absence podesty pro otevřený oheň v císařovnině kuchyni a topeniště s šachtami v kuchyni z tereziánské přsstavby Pražského hradu. Plány na zřízení korunovační kuchyně z 19. století i dochovaná konstrukce v suterénu Maxmiliánových kuchyní dokládají využívání topeništ's šachtami společně s tahovými sporáky ještě ve druhé polovině 19. století. 


\section{Prameny}

APH, SPS: Archiv Pražského hradu, fond Stará plánová sbírka.

APH, SPS-JMR: Archiv Pražského hradu, fond Stará plánová sbírka. Neznámý: sbírka plánů do r. 1918 jmenný a místopisný rejstř́ik, 1569-1918. Rejstř́ik, 1973, ev. č. 16.

SCAPPI, B., 1570: Opera di M. Bartolomeo Scappi, cuoco divisa in sei libri. Nel primo si contiene il ragionamento que fa l'autore con Gio. suo discepolo. Nel secondo si tratta di diverse vivande di carne, si di quadrupedi, come di volatili. Nel terzo si parla della statura e stagione de pesci. Nel quarto si mostra.

\section{Literatura}

BIEDERMANOVÁ, M.-CEJPOVÁ, M., 2017: Příspěvek k poznání topeništ' Ludvíkova křídla Pražského hradu - Ein Beitrag zur Erforschung der Feuerstätten im Ludwigsflügel der Prager Burg, CB 17, 99-134. CEJPOVÁ, M., v tisku: Kuchyně Pražského hradu.

SIROT, E., 2011: Allumer le feu. Paris.

ŠTAJNOCHR, V., 2017: Zámecké kuchyně. Praha.

VILÍMKOVÁ, M., 1972: Pražský hrad. Jižní křídlo. Stavebně historický průzkum. Dějiny. Ulož. v Archivu Pražského hradu ve Sbírce stavebně historických průzkumů, inv. č. 84.

VILÍMKOVÁ, M.-KAŠIČKA, F., 1976: Císařské kuchyně Pražského hradu, ZPP 36, 67-70.

\section{Zusammenfassung}

\section{Murello per pignatte. Feuerstätten mit Heizschächten in den Küchen der Prager Burg}

Die vorliegende Arbeit behandelt Küchenfeuerstätten mit auf einem Eisenrost in einem Schacht befindlichen Feuerungen, die in situ oder in Plandokumentationen auf der Prager Burg entdeckt wurden. Solche Feuerstätten hat man in französischer Umgebung als fourneau bzw. als potager bezeichnet, im Werk von Bartolomeo Scappi als murello per pignatte. Zwei Feuerstätten in situ (Ludwigsflügel, 4. und 5. Stockwerk) wurden in die zweite Hälfte des 16. Jahrhunderts datiert und enthalten drei Schächte, in denen ein Eisenrost untergebracht war. Vom Rost sind Abdrücke erhalten geblieben. Auf diesen Rost legte man woanders vorbereitete glühende Kohle, ggf. auch Holzkohle. Die Asche fiel durch den Rost in den unteren Teil des Schachtes, der im rechten Winkel abfiel und in der Wand der Feuerstätte, ggf. erst am Fußboden des Raumes eine Mündung hatte. Durch diese Bedienungsöffnung wurde die Asche entnommen. Der Brennvorgang und demnach auch die Brennintensität hat man wahrscheinlich durch die Luftzufuhr, d.h. durch Verdecken der Bedienungsöffnung reguliert, was offenbar auch durch die Form der Öffnung und die Größe des Gefäßes beeinflusst wurde, in dem man die Speisen gekocht oder erhitzt hat. Diese Feuerstätten mit Schacht sind bislang die ältesten solcherart, die man in der Tschechischen Republik entdeckt hat. Eine dritte Feuerstätte aus der zweiten Hälfte des 19. Jahrhunderts (Souterrain der sog. Maximiliansküchen, Südflügel der Prager Burg) funktionierte nach dem gleichen Prinzip, die Bedienungsöffnung wurde durch eine kleine Eisentür verschlossen. Weitere Feuerstätten mit Schacht konnten auf historischen Plänen entdeckt werden. Sie waren entweder isoliert und zumeist an der Außenmauer angemauert, oder Teil eines Podestes für offenes Feuer, das sich in der Regel am Rand von dessen kürzeren Seite befand. Einige Feuerstätten haben keinen Schornsteinanschluss, was die Annahme bestätigt, dass sie ein Minimum an Rauch produzierten, der durch das Fenster abziehen konnte. Sie befanden sich im Erdgeschoss der Maximiliansküchen (Pläne aus der ersten Hälfte des 18. Jahrhunderts), in der sog. Kaiserinnenküche im Südflügel (um 1722, dort ist das Fehlen eines Podestes für offenes Feuer interessant) und in der für die Krönung von Karl VI. im Jahr 1723 erbauten Küche. Man plante ihren Bau auch in den sog. Krönungsküchen, die im gotischen Stockwerk des Alten Palastes gebaut werden sollten. In den Plänen sind dort Feuerstätten mit Schächten zusammen mit 
Zugöfen eingezeichnet. Sie waren kein Bestandteil der großen Küche, die beim Umbau der Burg unter Maria Theresia (1757-1758) erbaut worden war, jedoch wurde diese Küche zusammen mit den im Souterrain befindlichen Maximiliansküchen betrieben.

Mgr. Miroslava Cejpová, Sopřeč 30, 53316 Vápno u Přelouče, Česká republika, cejpova@post.cz

Ing. arch. Magdalena Biedermanová, Vilímovská 24, 16000 Praha 6, Česká republika, magdalena.biedermanova@gmail.com 
